\title{
Parathyroid Gland Oxyphil Cell
}

National Cancer Institute

\section{Source}

National Cancer Institute. Parathyroid Gland Oxyphil Cell. NCI Thesaurus. Code C33269.

A cell of the parathyroid gland that has condensed chromatin in a small round nucleus. Its cytoplasm is composed of tightly packed mitochondria and glycogen granules, with rare secretory granules, stains pink, and the marg in is usually observed. 